\title{
Seven MADS-box Genes in Apple are Expressed in Different Parts of the Fruit
}

\author{
Jia-Long Yao, ${ }^{1}$ Yi-Hu Dong, Anders Kvarnheden, and Bret Morris \\ Gene Transfer and Expression Group, The Horticulture and Food Research Institute of New Zealand, \\ Private Bag 92 169, Auckland, New Zealand
}

\begin{abstract}
AdDitional INDEX words. fruit development, gene phylogeny, MADS-box, Malus $\times$ domestica
Abstract. To study the role of MADS-box genes in developing apples (Malus $\times$ domestica Borkh.), clones corresponding to seven different genes, $M d M A D S 5$ to $M d M A D S 11$, were isolated from a 2-day-old apple cDNA library. Through DNA sequence comparison, six genes were classified into the APETALA1 (AP1) group and one gene, MdMADS10, into the AGAMOUS (AG) group. Six of the genes, MdMADS5 to MdMADS10, were found to be preferentially expressed in fruit following pollination. These genes also showed differential expression patterns in core, cortex and skin of young fruit. For instance, MdMADS5, which is highly homologous to AP1, showed preferential expression in the cortex and skin tissues while MdMADS10, which is highly homologous to $A G L 11$, showed exclusive expression in the core tissues. The gene MdMADS11 showed a similar expression level and pattern in flowers, fruit at several early developmental stages, and for different fruit tissues. The range of expression patterns suggests that the genes play different roles in apple development.
\end{abstract}

MADS-box genes have been identified from a wide range of eukaryotic organisms including yeast, insects, mammals and plants (Shore and Sharrocks, 1995). They form a superfamily whose members share a highly conserved domain of 56 amino acids, named MADS-box after four of the originally cloned members: $\underline{M C M} 1, \underline{A G}, \underline{D E F A}$ and $\underline{\mathrm{S}} \mathrm{RF}$ (Shore and Sharrocks, 1995). The genes in this family encode transcription factors that have diverse roles in different developmental processes of eukaryotic organisms (Shore and Sharrocks, 1995; Yanofsky et al., 1990).

In plants, MADS-box genes have been shown to play fundamental roles in flower development by controlling floral meristem and floral organ identity (Coen and Meyerowitz, 1991; Davies and Schwarz-Sommer, 1994; Weigel and Meyerowitz, 1994). APETALAl (APl), an arabidopsis [Arabidopsis thaliana (L.) Heynh] meristem identity gene, controls the transition from vegetative meristem to floral meristem (Mandel et al., 1992, Mandel and Yanofsky, 1995). Homologs to APl also have been cloned from Antirrhinum majus L. (Huijser et al., 1992) and maize (Zea mays L.) (Mena et al., 1995). The floral organ identity MADS-box genes have been grouped into three different classes by function according to the proposed ABC model (Coen and Meyerowitz, 1991; Weigel and Meyerowitz, 1994). In summary for arabidopsis, the class A gene API specifies sepal formation; classes A and B [APETALA3 (AP3) and PISTILLATA (PI)] genes together specify petal formation; classes $\mathrm{B}$ and $\mathrm{C}[A G A M O U S(A G)]$ genes together are required for stamen formation; and class $\mathrm{C}$ genes alone control carpel formation (Weigel and Meyerowitz, 1994). More recently, a class D gene (FBP11) has been described in petunia (Petunia hybrida Vilm.) controlling ovule development (Angenent et al., 1995; Colombo et al., 1995).

The relatively high DNA sequence conservation within the MADS-box of these genes has permitted isolation of additional gene members from arabidopsis by means of cross hybridization using homologous DNA probes or through PCR amplification using degenerative primers (Ma et al., 1991, Rounsley et al., 1995). Similar methods have been used to clone MADS-box genes from

Received for publication 13 Apr. 1998. Accepted for publication 16 Sept. 1998. This research was supported by New Zealand Foundation For Research, Science, and Technology (contract no. C06411). The cost of publishing this paper was defrayed in part by the payment of page charges. Under postal regulations, this paper therefore must be hereby marked advertisement solely to indicate this fact. ${ }^{1}$ To whom reprint requests should be addressed. a variety of different plant species including tomato (Lycopersicon esculentum Mill.) (Pnueli et al., 1991), rice (Oryza sativa L.) (Chung et al., 1994; Kang et al., 1995), Norway spruce [Picea abies (L.) Karsten] (Tandre et al., 1995), Sinapis alba L. (Menzel et al., 1996), potato (Solanum tuberosum L.) (Kang and Hannapel, 1996), Pinus radiata D. Don (Mouradov et al., 1996), Sorghum bicolor (L.) Moench (Greco et al., 1997), apple (Sung and An, 1997], and cucumber (Cucumis sativus L.) (Filipecki et al., 1997). Although the majority of MADS-box genes isolated so far show floral specific expression, additional genes have alternative expression patterns in a range of plant tissues including; leaves, roots, embryos (Rounsley et al., 1995), fruit (Sung and An, 1997), embryogenic callus (Filipecki et al., 1997) and potato tubers (Kang and Hannapel, 1996). This diverse range of expression patterns for MADS-box genes suggest that they are likely to play roles in many other aspects of plant development in addition to their role in flowering.

Following floral organ specification and anthesis, fruit development starts with a rapid cell division phase which is normally stimulated by pollination and fertilization, and continues through a cell expansion phase to ripening (Gillaspy et al., 1993). Relatively few studies have been undertaken to characterize the molecular basis of fruit development. Most molecular studies on fruit have concentrated on fruit ripening through the characterization of ethylene biosynthesis genes (Bolitho et al., 1997; Grierson and Fray, 1994; Hamilton et al., 1990) and cell wall softening genes such as polygalacturonase (Kramer and Redenbaugh, 1994, Watson et al., 1994). A few cDNA clones have been isolated from young fruit cDNA libraries using differential screening (Dong et al., 1997; Ledger and Gardner, 1994; Santino et al., 1997) or differential display techniques (Tieman and Handa, 1996). However, the role of most of these genes in fruit development remains to be determined. Processes occurring during the cell division phase are critical to determine final fruit size, shape and quality. We were interested in isolating genes contributing important roles in the cell division phase of apple development and have chosen to work on MADS-box genes because they influence biological development through control of cell fate and differentiation (Shore and Sharrocks, 1995).

Apple falls into the pome fruit category. The fruit core develops from an inferior ovary which is surrounded by the floral tube developing into fruit flesh (Pratt, 1988). This type of fruit structure 
differs from tomato, a model system often used in studies of fruit development, where the fruit develops from ovary tissue only (Gillaspy et al., 1993). Developmental processes in apples, particularly in the cortex tissue, are likely to be very different from those in tomato. Therefore, molecular studies in apple development may be useful in further defining these differences. In this report, we describe the isolation of seven MADS-box genes from a cDNA library of young apples and provide evidence for their involvement in fruit development.

\section{Materials and Methods}

PCR AMPLIFICATION OF MADS-BOX DNA FRAGMENTS. Total RNA was isolated from 'Granny Smith' apples at $2 \mathrm{~d}$ after pollination using the method described by Chang et al. (1993). Poly(A) mRNA was purified from the total RNA using the mRNA Purification Kit (Pharmacia, Sweden). cDNA was synthesized from the mRNA using the ZAP cDNA Synthesis Kit (Stratagene). MADS-box DNA fragments were amplified from templates of cDNA using two degenerative PCR primers: 5'-CGGAATTCATGGGNMGNGGNAARRT-3', 5'-CGGGATCCACYTCNGCRTCRCANA-3' ( $N=$ ATGC, $M=A C, R=A G, Y=C T)$. The primers were designed according the conserved amino acid sequences MGRGKV/I and LCDAEV in the MADS-box domain. The underlined Eco RI and Bam HI sites were used for cloning the PCR products. The PCR amplification conditions were as follows: initial denaturation at $94{ }^{\circ} \mathrm{C}$ for $5 \mathrm{~min}$; then 40 cycles of $94{ }^{\circ} \mathrm{C}$ for $1 \mathrm{~min}, 55^{\circ} \mathrm{C}$ for $1 \mathrm{~min}$, and $72{ }^{\circ} \mathrm{C}$ for $1.5 \mathrm{~min}$; and with a final extension of $5 \mathrm{~min}$ at $72^{\circ} \mathrm{C}$. Several bands were detected from the PCR on agarose gels and DNA in a band of the expected size (145 bp) was cloned into Bluescript SK (Stratagene) following Eco RI and Bam HI digestion.

CONSTRUCTION OF A CDNA LIBRARY AND SCREENING FOR MADSBOX CLONES. A ZAPII (Stratagene) library was constructed using cDNA as used for the PCR amplification. About $1 \times 10^{5}$ phage colonies from the library were then screened on Hybond- $\mathrm{N}^{+}$nylon membranes (Amersham, England) using a mix of seven different ${ }^{32} \mathrm{P}$-dCTP labelled MADS-box DNA fragments. The membranes were hybridized in $0.5 \mathrm{M} \mathrm{NaPO}_{4}$ buffer ( $\mathrm{pH} 7.2$ ) with 1 mM EDTA and $7 \%$ SDS at $65^{\circ} \mathrm{C}$ and washed using $0.4 \times$ SSC and $0.2 \%$ SDS at $65^{\circ} \mathrm{C}$.

DNA SEQUENCE DETERMINATION. Nucleotide sequences of MADSbox clones were determined using the automatic sequencer ABI PRISM model 377 with universal forward and reverse primers. To obtain complete sequences, cDNA clones were further subcloned in Bluescript and both DNA strands were sequenced.

COMPARISON ANALYSES OF DNA SEQUENCES. Nucleotide and predicted amino acid sequences for one Pinus radiata and nine different arabidopsis MADS-box genes were selected from GenBank. These sequences were then used together with the seven apple genes, MdMADS5 to MdMADS11, to produce both amino acid and nucleotide sequence alignments using the PILEUP program of the GCG package (version 9; Genetics Computer Group, Madison, Wis.). The nucleotide sequence alignment was visually refined using the amino acid alignment as a guide. The first and second codon positions in the MADS-box and K-box were used for phylogenetic analysis using parsimony methods in the PAUP program (Swofford, 1993). The tree was constructed from the results of 100 bootstrap replicates using the PAUP heuristic search.

NORTHERN ANALYSIS USING MADS-BOX CLONES ON APPLE TISSUES. Total RNA was isolated as in Chang et al. (1993) from 'Granny Smith' apple tissues. Northern blots were prepared by transferring RNA to Hybond- $\mathrm{N}^{+}$nylon membranes following agarose gel electrophoresis under denaturing conditions (Dong et al., 1997). The first northern blot contained RNA isolated from expanding leaves, unopened flowers, and fruit at $2 \mathrm{~d}$ and 1, 4, and 8 weeks following hand-pollination. At 4 weeks after pollination, apples are large enough to allow for easy separation into the three main tissue types, namely; core, cortex, and skin. In order to determine the relative gene expression patterns for apple MADS-box genes within fruit, the second northern blot was made using RNA isolated from these three fruit parts. Northern blots were sequentially probed with ${ }^{32} \mathrm{P}-\mathrm{dCTP}$ labelled MADS-box cDNA clones lacking the MADS-box sequence to significantly reduce cross hybridization. Finally, members were hybridized to an $18 \mathrm{~S}$ rDNA probe from apple (Simon and Weeden, 1992) for assessment of even loadings of RNA. The hybridization and washing conditions were the same as those in cDNA library screening. Membranes for reprobing with different MADS-box gene clones and rDNA were stripped by pouring on boiling $0.5 \%$ SDS and allowing it to cool to room temperature, as recommended by the manufacturer (Amersham, England).

\section{Results}

ISOLATION AND SEQUENCE ANALYSIS OF SEVEN DIFFERENT APPLE MADS-BOX GENES. DNA fragments of $145 \mathrm{bp}$ were amplified from

Table 1. Size of cloned apple MADS-box genes and comparison of their deduced amino acid sequence to putative homologues.

\begin{tabular}{|c|c|c|c|c|c|c|c|}
\hline \multirow[b]{2}{*}{ Clone } & \multirow{2}{*}{$\begin{array}{c}\text { EMBL } \\
\text { accession no. }\end{array}$} & \multirow{2}{*}{$\begin{array}{l}\text { No. } \\
\text { bp }\end{array}$} & \multirow{2}{*}{$\begin{array}{l}\text { No. } \\
\text { AAs }\end{array}$} & \multicolumn{4}{|c|}{ Sequence identity with related genes $(\%)^{z}$} \\
\hline & & & & Gene & MADS & K-box & Overall \\
\hline MdMADS5 & AJ000759 & 1055 & 239 & AP1 & 94.6 & 71.6 & 71.0 \\
\hline \multirow{2}{*}{ MdMADS6 } & AJ000760 & 972 & 248 & PrMADS1 & 94.6 & 66.5 & 50.7 \\
\hline & & & & MdMADS7 & 91.1 & 80.6 & 83.1 \\
\hline MdMADS7 & AJ000761 & 1177 & 248 & PrMADS1 & 96.4 & 77.6 & 71.8 \\
\hline \multirow[t]{4}{*}{ MdMADS8 } & AJ001681 & 1291 & 246 & MdMADS1 & 100 & 100 & 99.6 \\
\hline & & & & AGL2 & 100 & 91.0 & 80.7 \\
\hline & & & & AGL4 & 96.4 & 88.1 & 74.3 \\
\hline & & & & MdMADS9 & 98.2 & 94.0 & 93.4 \\
\hline \multirow[t]{2}{*}{ MdMADS9 } & AJ001682 & 964 & 246 & AGL2 & 98.2 & 86.6 & 76.3 \\
\hline & & & & AGL4 & 98.2 & 82.1 & 73.8 \\
\hline \multirow[t]{2}{*}{ MdMADS10 } & AJ000762 & 877 & 207 & AGL11 & 96.4 & 62.7 & 78.2 \\
\hline & & & & FBP7 & 91.1 & 53.7 & 65.9 \\
\hline MdMADS11 & AJ000763 & 1240 & 243 & AGL6 & 96.4 & 76.0 & 67.0 \\
\hline
\end{tabular}

${ }^{\bar{z}}$ The numbers are percentages of amino acid identities in the MADS-box domain, in the K-box domain and over the full gene. 
apple cDNA using degenerative PCR primers against conserved sequences in the MADS-box. After these DNA fragments were cloned, nine random clones were sequenced. Seven clones were

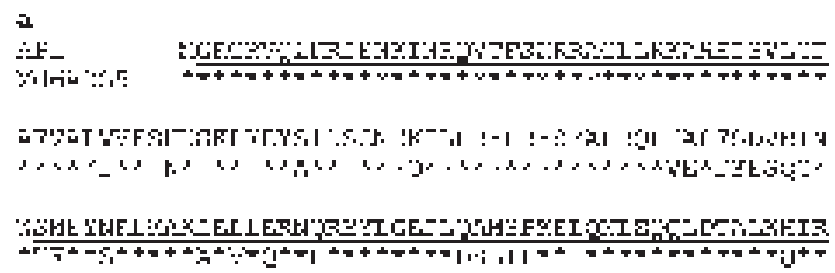

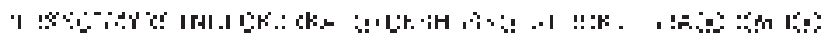

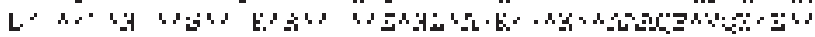

ذب: 4

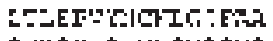

$+3+\cdots+1,1+\cdots+\cdots+$

羊

5i:I:

سI-I 1

Yat:iri미:!

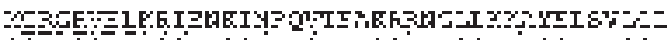

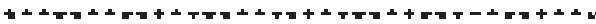

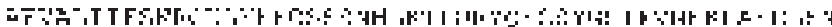

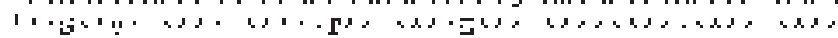

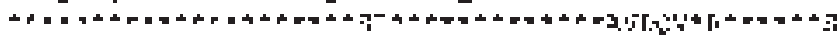
A r...

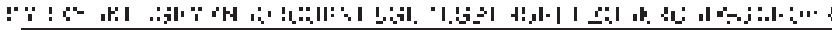

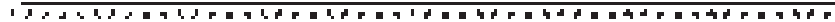

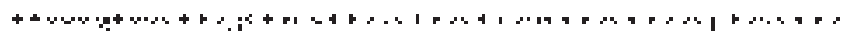

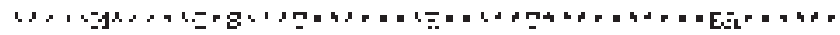

E I

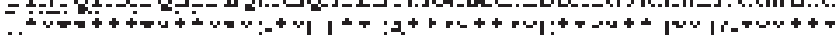

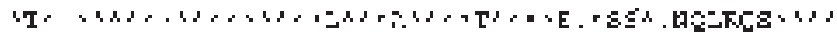

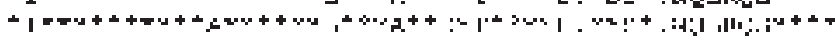

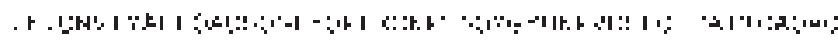

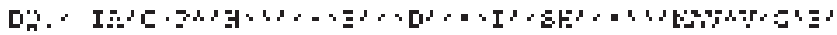

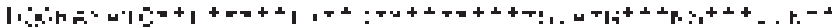
"

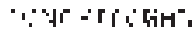

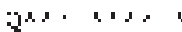

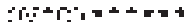

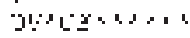

[

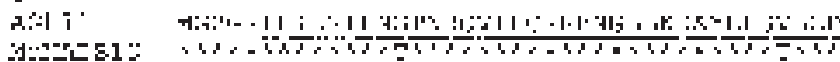

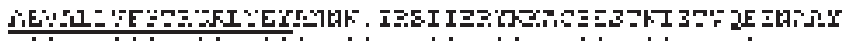

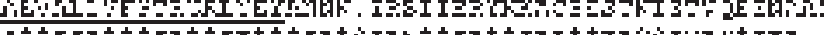

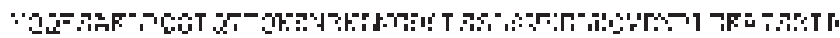

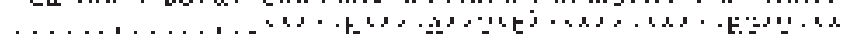

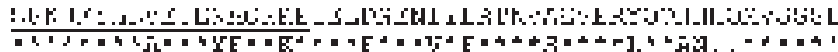

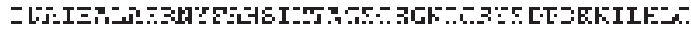

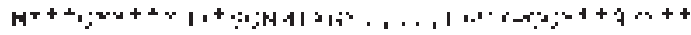

Fig. 1. Sequence alignments between predicted MADS-box proteins. (a) Alignment between the deduced peptides MdMADS5 and AP1 (Mandel et al., 1992) of Arabidopsis. (b) Alignment between the deduced peptides MdMADS8, MdMADS9 and AGL2 (Ma et al., 1991) of Arabidopsis. (c) Alignment between the deduced peptides MdMADS10 and AGL11 (Rounsley et al., 1995) of Arabidopsis. The N-terminal MADS-box and the central K-box are underlined. Asterisks indicate amino acid identity, while dots indicate gaps introduced to maximise alignments. found to contain independent MADS-box DNA sequences, while one showed strong homology to a histone H2A gene, and the remaining clone had no homology to any entry within the database. Using a mixture of the seven different MADS-box cloned fragments to screen a cDNA library prepared from apple mRNA at 2 $\mathrm{d}$ after pollination, 11 positive cDNA clones were isolated, representing seven independent genes as determined by partial sequencing. Only one of the cDNA clones had an identical sequence to one of the seven PCR clones.

The entire nucleotide sequences of the seven cDNA clones containing different MADS-box sequences were determined and submitted to the EMBL database. These clones were named as MdMADS5 to MdMADS11 (Malus domestica MADS) following the numbering system used in a recent study of apple MADS-box genes (Sung and An, 1997). All seven clones contain a putative open reading frame, a 3' untranslated region, and a poly(A) tail. There was a 5' untranslated region between 11 bp and 374 bp for MdMADS5, MdMADS7, MdMADS8, MdMADS10, and MdMADS11. The size of each clone and their deduced peptides are summarized in Table 1. All deduced peptides contain the MADS-box domain (although MdMADS6 and MdMADS9 lack three and four amino acids, respectively, at the $\mathrm{N}$-terminus being only partial sequences), the $\mathrm{K}$ box domain, an intervening region between the MADS-box and the $\mathrm{K}$-box, and a C-terminal region. These features confirm that the clones belong to the MADS-box gene family.

Comparisons of deduced amino acid sequence revealed a high level of sequence similarity between MdMADS6 and MdMADS7, as well as between MdMADS8 and MdMADS9 (Table 1, Fig. 1b). Comparisons made with the predicted amino acid sequence from each of the seven apple MADS-box genes and the GenBank database using BLAST searching revealed that MdMADS5 had highest homology with AP1 (Mandel et al., 1992); MdMADS6 and MdMADS7 with PrMADS1 (Mouradov et al., 1996); MdMADS8 and MdMADS9 with AGL2 and AGL4 (Ma et al., 1991); MdMADS10 with AGL11 (Rounsley et al., 1995) and FBP7 (Angenent et al., 1995); and MdMADS11 with AGL6 (Ma et al., 1991). The percentage of amino acid sequence identity between these genes over the entire sequence, in the MADS-box domain and in the K-box domain, are listed in Table 1.

An amino acid alignment of MdMADS5 and AP1 showed that

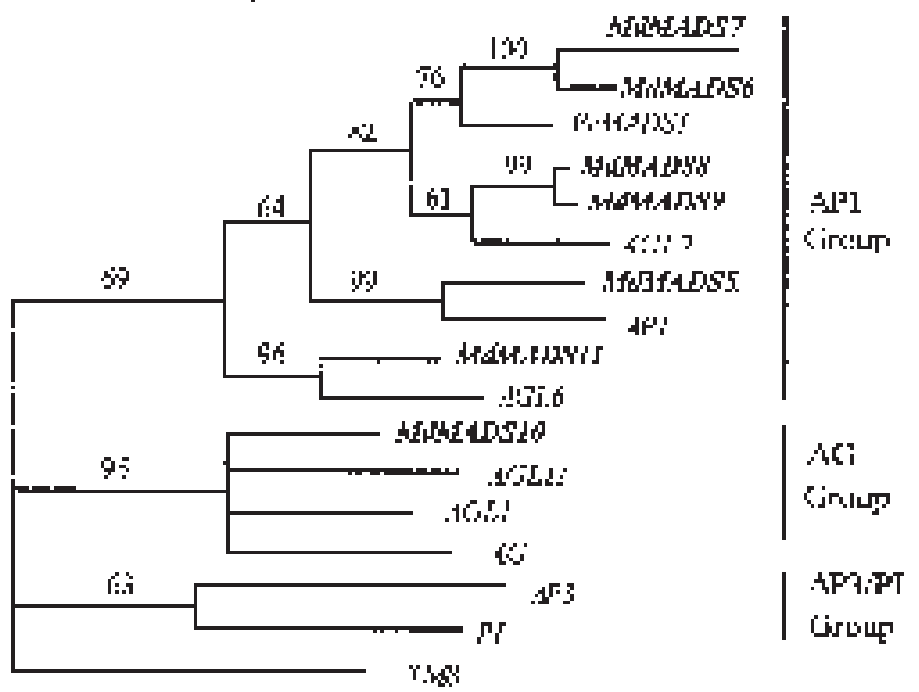

Fig. 2. Phylogenetic tree of selected plant MADS-box genes using parsimony analysis. The numbers next to the nodes give bootstrap values from 100 replicates. Nodes with $<50 \%$ bootstrap support are collapsed. 
a 17 amino acid segment in the C-terminal region of AP1 was apparently absent in MdMADS5 although these two proteins are highly conserved in the MADS-box and in the C-terminus (Fig. 1a). MdMADS8 and AGL2 showed an overall amino acid identity of $80.7 \%$, with total sequence identity in MADS-box domains and over six amino acids in the C-terminus (Table 1, Fig. 1b). MdMADS10 contained a deletion of 17 amino acids, mostly in the K-domain, when compared to AGL11 (Fig. 1c).

Most plant MADS-box genes have been classified into three groups following phylogenetic analysis: the $A P 1$ group, $A G$ group and $P I / A P 3$ group. In general, genes within each group have similar function and expression patterns (Purugganan et al., 1995; Rounsley et al., 1995). Using a similar analysis procedure, we classified MdMADS10 into the $A G$ group and the six remaining apple genes, MdMADS5 to MdMADS9 and MdMADS11 into the $A P 1$ group (Fig. 2). Using our screening procedure, we obtained no apple genes from the PI/AP3 group.

TIMING OF APPLE MADS-BOX GENE EXPRESSION DURING FRUIT DEVELOPMENT. Expression was not readily detected in apple leaf tissue for any of these genes. The apparent mRNA level for $M d M A D S 5$ to $M d M A D S 10$ was lower in unpollinated flowers but markedly increased in fruit tissue $2 \mathrm{~d}$ after pollination (Fig. 3).

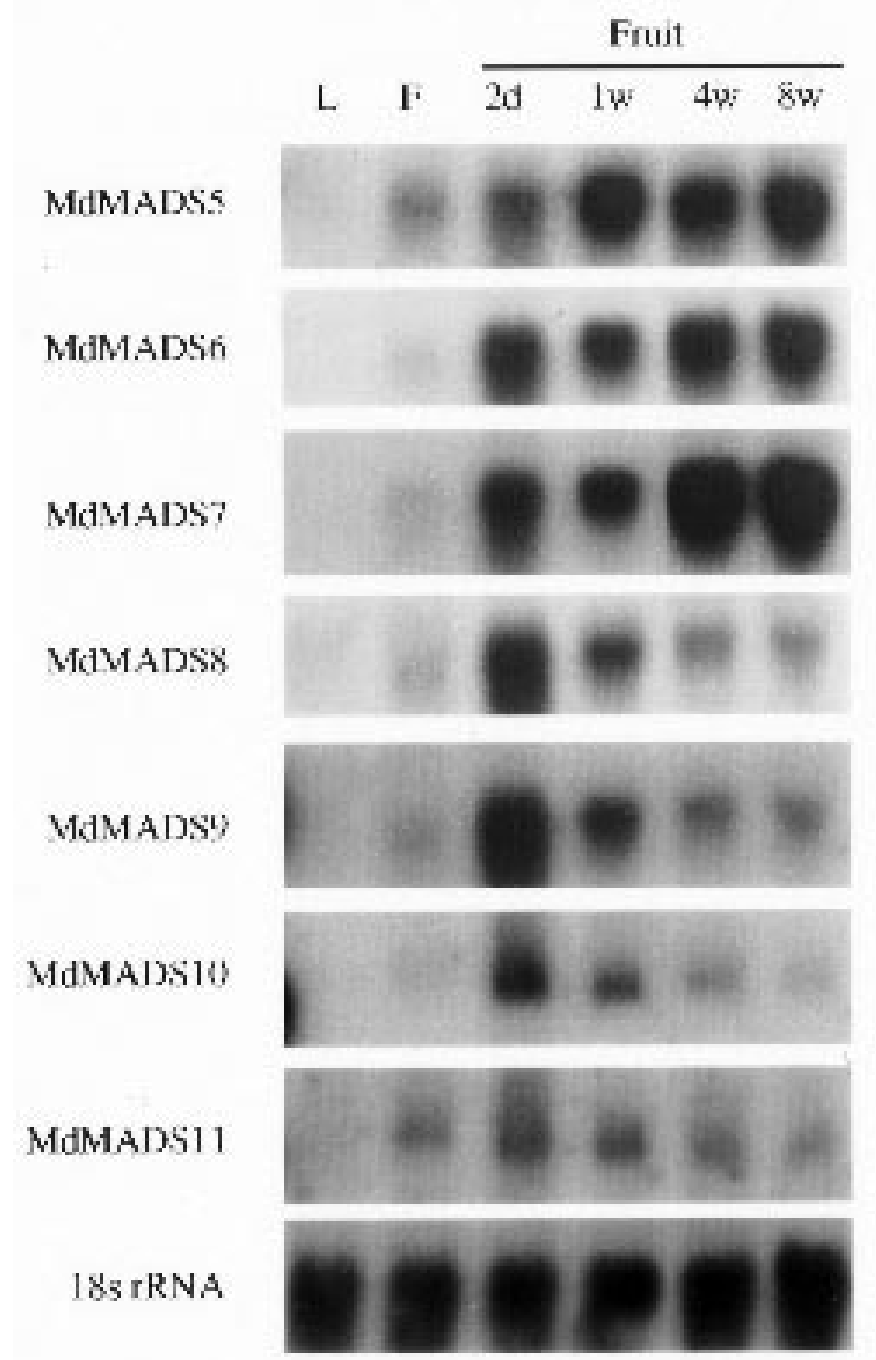

Fig. 3. Expression of seven apple MADS-box genes as determined by northern analysis. Total RNA was used from young leaves (L), flower buds (F) and fruit at $2 \mathrm{~d}(2 \mathrm{~d})$, and 1, 4 and 8 weeks (1w, 4w, 8w) after pollination. One northern blot was sequentially probed with gene-specific probes for the genes shown at left. The rDNA probe was used as a loading control.
Expression of MdMADS5 was further stimulated at 1 week after pollination, possibly a result of fertilization since this process in apple takes approximately one week to occur (Williams, 1965). $M d M A D S 5$ remained at the same expression level at 4 and 8 weeks. $M d M A D S 6$ showed a relatively constant expression level between $2 \mathrm{~d}$ and 8 weeks, while the expression of $M d M A D S 7$ was strongest at 4 and 8 weeks compared to 2-d and 1-week fruit. MdMADS8, MdMADS9, MdMADS10 and MdMADS11 shared a similar expression pattern with the highest transcript level being detected at $2 \mathrm{~d}$ after pollination followed by a gradual decrease in expression. Hybridization result to an 18 s rDNA probe showed even loadings of RNA samples on the northern blot.

APPLE MADS-BOX GENES ARE EXPRESSED IN DIFFERENT PARTS OF THE FRUIT. The seven MADS-box genes were differentially expressed in fruit tissue, producing five different expression patterns (Fig. 4). MdMADS5 was strongly expressed in cortex and skin but very weakly expressed in the core. MdMADS6 and MdMADS7 had a higher expression level in the cortex and skin than in core although significant levels of expression were found in the core tissue. In contrast, the expression of MdMADS8 and MdMADS9 was stronger in the core and cortex but weaker in skin. MdMADS10 expression could only be detected in the core while MdMADS11 was evenly expressed in the three different fruit tissues (Fig. 4).

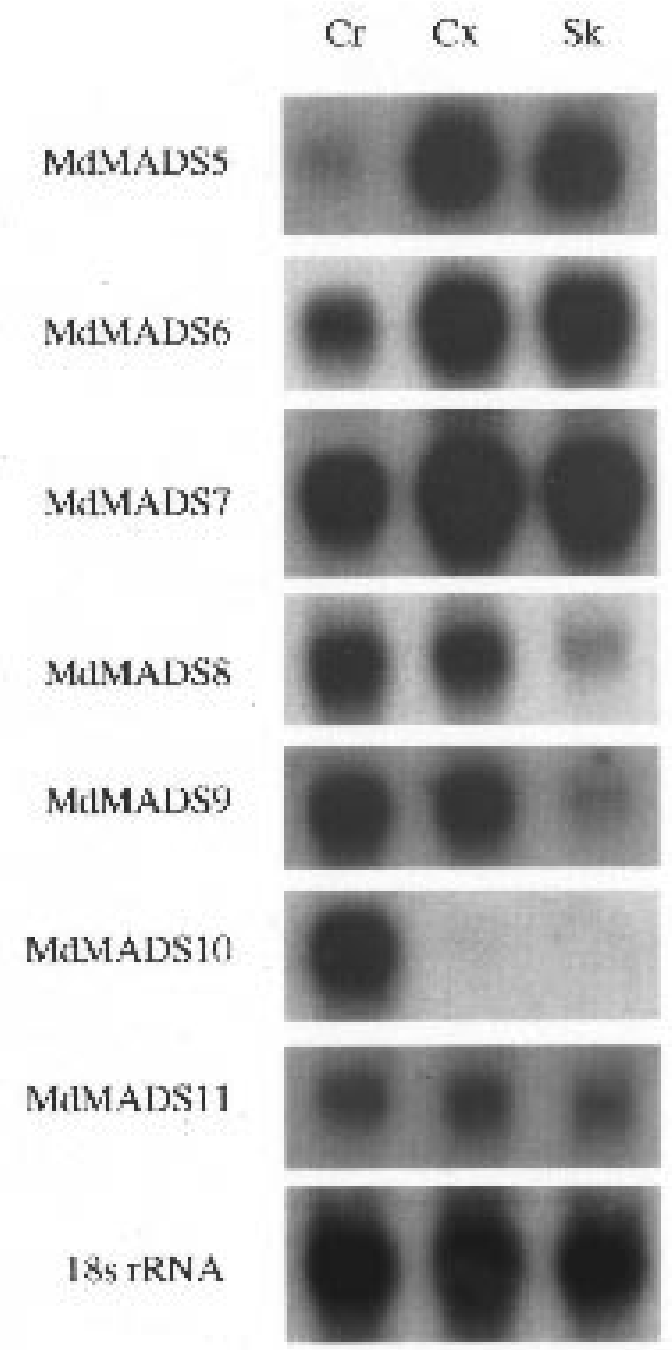

Fig. 4. Expression of seven apple MADS-box genes in different parts of the apple as determined by northern analysis. Total RNA was used from core $(\mathrm{Cr})$, cortex $(\mathrm{Cx})$ and skin (Sk) of apples at 4 weeks after pollination. One northern blot was sequentially probed with gene-specific probes for the genes shown at left. The rDNA probe was used as a loading control. 


\section{Discussion}

Apples are pome, having a fleshy cortex in addition to a core derived from the ovary. The cortex tissue develops from the floral tube, which consists of the fused bases of the sepals, petals and stamens according to the appendicular hypothesis [for review, (Pratt, 1988)]. In arabidopsis $A P I$ is expressed in young flower primordia to specify the identity of flower meristems and later in sepals and petals to determine the development of these two floral organs (Mandel et al., 1992). The expression of the APl-like gene $M d M A D S 5$ in apple cortex and skin is consistent with the probable origin of these tissues from sepal and petal bases. Of the seven MADS-box clones isolated, six were classified into the APl group and one into the $A G$ group (Fig. 1). From the additional six MADSbox gene fragments amplified from apple cDNA using degenerative PCR primers, five fit into the $A P 1$ group and one into the $A G$ group (data not shown). However, we have not been able to isolate MADS-box genes with significant sequence identity to $A P 3$ or $P I$, which are both expressed in the petals and stamens (Goto et al., 1993; Jack et al., 1992). If petals, stamens and sepals contribute equally to apple cortex formation, we would have expected to detect some members of the $A P 3 / P I$ group as the degenerative primers used should be able to amplify AP3-like or PI-like genes. These data suggest that the cortex tissue develops mainly from the bases of sepals and that the cells of petals and stamens have little or no contribution to cortex formation.

The putative products of MdMADS8 and MdMADS9 show extensive similarity to AGL2 of arabidopsis (Ma et al., 1991). In situ hybridization experiments have previously shown that the AGL2 transcript is present in all four whorls of the flower during floral organ meristem development and during morphological differentiation of organs, but absent at the final maturation phase of development. The AGL2 gene also is expressed early in seed and embryo development. Flanagan and Ma (1994) proposed that AGL2 functions in the early development of all floral organs and ovules. Within the coding region, MdMADS8 was almost completely identical to the previously isolated apple MADS-box gene MdMADS1 (Sung and An, 1997), with only one nucleotide differing. The nucleotide sequence of $M d M A D S 8$ was 346 bp longer in the 5' untranslated region and $46 \mathrm{bp}$ shorter in the 3 ' untranslated region compared to $M d M A D S 1$, in addition to one nucleotide difference in the 3' untranslated region. MdMADS1 and MdMADS8 are likely to represent the same gene with the differences likely due to different apple cultivars [their Fuji (Sung and An, 1997) vs our Granny Smith] or to variations in cDNA synthesis and sequence analysis. Sung and An (1997) have shown that MdMADS1 has a similar expression to $A G L 2$ in floral organs. Our data show that the expression level of MdMADS8 and MdMADS9 is high in fruit tissue after pollination and then gradually decreases (Fig. 3). It is, therefore, possible that $M d M A D S 8$ and $M d M A D S 9$ play an important role in the early process of apple development.

The predicted protein sequence of MdMADS10 has a high level of homology to FBP7 and AGL11, which have a role in the control of ovule and seed development (Angenent et al., 1995; Colombo et al., 1995; Colombo et al., 1997; Rounsley et al., 1995). MdMADS10 mRNA was only detected in the fruit core (Fig. 4), which develops from ovary tissue and contains the seeds. No signal was detected in the cortex sample that included a small amount of outer core tissue. This suggests that MdMADS10 is expressed in the central core tissue, possibly in the seed. Expression of MdMADS10 mRNA in apple ovule integuments and seed coat was detected by in situ hybridization techniques (Yao, unpublished data). MdMADS10 may, therefore, play an important role in ovule and seed development. Since seed development has a significant impact on fruit development (Gillaspy et al., 1993), manipulation of MdMADS10 expression may also influence this process.

Previous studies on plant MADS-box genes have concentrated largely on flower development (Davies and Schwarz, 1994; Theißen and Saedler, 1995). In one such study, an apple MADS-box gene isolated from a flower bud cDNA library was found to be expressed in fruit tissue (Sung and An, 1997). In our work, we are interested in characterizing the role of MADS-box genes in apple development and have begun by isolating seven different MADSbox clones from a cDNA library constructed from 'Granny Smith' apples at $2 \mathrm{~d}$ after pollination. Six of these genes were preferentially expressed in fruit tissue $2 \mathrm{~d}$ following pollination and they were found to be expressed in different parts of the fruit. On the basis of temporal and spatial differences in their expression, we postulate that these genes play several different roles in apple development.

\section{Literature Cited}

Angenent, G.C., J. Franken, M. Busscher, A. van Dijken, J.L.van Went, H.J.M. Dons, and A.J. van Tunen. 1995. A novel class of MADS box genes is involved in ovule development in petunia. Plant Cell 7:1569_ 1582.

Bolitho, K.M, M. Lay-Yee, M.L. Knighton, and G.S. Ross. 1997. Antisense apple ACC-oxidase RNA reduces ethylene production in transgenic tomato fruit. Plant Sci. 122:91-99.

Chang, S., J. Puryear, and J. Cairney. 1993. A simple and efficient method for isolating RNA from pine trees. Plant Mol. Biol. Rpt. 11:113-116.

Chung, Y.-Y., S.-R. Kim, D. Finkel, M.F. Yanofsky, and G. An. 1994. Early flowering and reduced apical dominance result from ectopic expression of a rice MADS box gene. Plant Mol. Biol. 26:657-665.

Coen, E.S. and E.M. Meyerowitz. 1991. The war of the whorls: genetic interactions controlling flower development. Nature 353:31-37.

Colombo, L., J. Franken, E. Koetje, J.L. van Went, G.C. Angenent, H.J.M. Dons, and A.J. van Tunen. 1995. The petunia MADS box gene FBP11 determines ovule identity. Plant Cell 7:1859-1868.

Colombo, L., J. Franken, A.R. Van der Krol, P.E. Wittich, H.J.M. Dons, and G.C. Angenent. 1997. Downregulation of ovule-specific MADS box genes from petunia results in maternally controlled defects in seed development. Plant Cell 9:703-715.

Davies, B. and Z. Schwarz-Sommer. 1994 Control of floral organ identity by homeotic MADS box transcription factors. Results Probl. Cell Differ. 20:235-258.

Dong, Y-H, B.-J. Janssen, L.E.F. Bieleski, R.G. Atkinson, B.A.M. Morris, and R.G. Gardner. 1997. Isolating and characterizing genes differentially expressed early in apple fruit development. J Amer Soc Hort Sci 122:752-757.

Filipecki, M.K., H. Sommer, and S. Malepszy. 1997. The MADS-box gene CUS1 is expressed during cucumber somatic embryogenesis. Plant Sci. 125:63-74.

Flanagan, C.A. and H. Ma. 1994. Spatially and temporally regulated expression of the MADS-box gene AGL2 in wild-type and mutant arabidopsis flowers. Plant Mol. Biol. 26:581-595.

Gillaspy, G., H. Ben-David, and W. Gruissem. 1993. Fruits: a developmental perspective. Plant Cell 5:1439-1451.

Goto, K. and E.M. Meyerowitz. 1993. Function and regulation of the Arabidopsis floral homeotic gene PISTILLATA. Genes Dev. 8:15481560.

Greco, R., L. Stagi, L. Colombo, G.C. Angenent, M. Sari-Gorla, and M.E. Pe. 1997. MADS box genes expressed in developing inflorescences of rice and sorghum. Mol. Gen. Genet. 253:615-623.

Grierson, D. and R. Fray. 1994. Control of ripening in transgenic tomatoes. Euphytica 79:251-263.

Hamilton, A.J., G.W. Lycett, and D. Grierson. 1990. Antisense gene that inhibits synthesis of the hormone ethylene in transgenic plants. Nature 346:284-287.

Huijser, P., J. Klein, W.-E. Lönnig, H. Meijer, H. Saedler, and H. Sommer. 
1992. Bracteomania, an inflorescence anomaly, is caused by the loss of function of the MADS-box gene squamosa in Antirrhinum majus. EMBO J. 11:1239-1249.

Jack, T., L.L. Brockman, and E.M. Meyerowitz. 1992 The homeotic gene APETALA3 of Arabidopsis thaliana encodes a MADS box and is expressed in petals and stamens. Cell 68:683-697.

Kang, H.-G., Y.-S. Noh, Y.-Y. Chung, M.A. Costa, K. An, and G. An. 1995. Phenotypic alterations of petal and sepal by ectopic expression of a rice MADS box gene in tobacco. Plant Mol. Biol. 29:1-10.

Kang, S.-G. and D.J. Hannapel. 1996. A novel MADS-box gene of potato (Solanum tuberosum L.) expressed during the early stages of tuberization. Plant Mol. Biol. 31:379-386.

Kramer, M.G. and K. Redenbaugh. 1994. Commercialization of a tomato with an antisense polygalacturonase gene: The FLAVR SAVR tomato story. Euphytica 79:293-297.

Ledger, S.E. and R.G. Gardner. 1994 Cloning and characterization of five cDNAs for genes differentially expressed during fruit development of kiwifruit (Actinidia deliciosa var. deliciosa). Plant Mol. Biol. 25:877886.

Ma, H., M.F. Yanofsky, and E.M. Meyerowitz. 1991. AGL1-AGL6, an Arabidopsis gene family with similarity to floral homeotic and transcription factor genes. Genes Dev. 5:484-495.

Mandel, M.A., C. Gustafson-Brown, B. Savidge, and M.F. Yanofsky. 1992. Molecular characterization of the Arabidopsis floral homeotic gene APETALA1. Nature 360:273-277.

Mandel, M.A. and M.F. Yanofsky. 1995. A gene triggering flower formation in Arabidopsis. Nature 377:522-524.

Mena, M., M.A. Mandel, D.R. Lerner, M.F Yanofsky, and R.J. Schmidt. 1995. A characterization of the MADS-box gene family in maize. Plant J. 8:845-854.

Menzel, G., K. Apel, and S. Melzer. 1996. Identification of two MADS box genes that are expressed in the apical meristem of the long-day plant Sinapis alba in transition to flowering. Plant J. 9:399-408.

Mouradov, A., T. Glassick, G.A. Vivian-Smith, and R. Teasdale 1996. Isolation of a MADS box gene family from Pinus radiata (Accession No. U42399 and U42400) (PGR 96-002). Plant Physiol. 110:1047.

Pnueli, L., M. Abu-Abeid, D. Zamir, W. Nacken, Z. Schwarz-Sommer, and E. Lifschitz. 1991. The MADS box gene family in tomato: temporal expression during floral development, conserved secondary structures and homology with homeotic genes from Antirrhinum and Arabidopsis. Plant J. 1:255-266.

Pratt, C. 1988. Apple flower and fruit: Morphology and anatomy. Hort.
Rev. 10:273-307.

Purugganan, M.D., S.D. Rounsley, R.J. Schmidt, and M.F. Yanofsky. 1995. Molecular evolution of flower development: Diversification of the plant MADS-box regulatory gene family. Genetics 140:345-356.

Rounsley, S.D, G.S. Ditta, and M.F. Yanofsky. 1995. Diverse roles for MADS box genes in Arabidopsis development. Plant Cell 7:1259-1269.

Santino, C.G., G.L. Stanford, and T.W.Conner. 1997. Developmental and transgenic analysis of two tomato fruit enhanced genes. Plant Mol. Biol. 33:405-416.

Schwarz-Sommer, Z., P. Huijser, W. Nacken, H. Saedler, and H. Sommer. 1990. Genetic control of flower development by homeotic genes in Antirrhinum majus. Science 250:931-936.

Shore, P. and A.D. Sharrocks. 1995. The MADS-box family of transcription factors. Eur. J. Biochem. 229:1-13.

Simon, C.J. and N.F. Weeden. 1992. Molecular analysis and cloning of Malus ribosomal DNA. J. Amer. Soc. Hort. Sci. 117: 164-168 (1992).

Sung, S.K. and G. An. 1997. Molecular cloning and characterization of a MADS box cDNA clone of the Fuji apple. Plant Cell Physiol. 38:484489.

Swofford, D.L. 1993. PAUP: Phylogenetic analysis using parsimony. version 3.1s. Ill. Natl. History Survey, Champaign.

Tandre, K., V.A. Albert, A. Sundås, and P. Engström. 1995. Conifer homologues to genes that control floral development in angiosperms. Plant Mol. Biol. 27:69-78.

Theißen, G. and H. Saedler. 1995. MADS-box genes in plant ontogeny and phylogeny: Haeckel's 'biogenetic law' revisited. Curr. Opin. Genet. Dev. 5:628-639.

Tieman, D.M. and A.K. Handa. 1996. Molecular cloning and characterization of genes expressed during early tomato (Lycopersicon esculentum Mill.) fruit development by mRNA differential display. J. Amer. Soc. Hort. Sci. 121:52-56.

Watson, C.F., L. Zheng, and D. Dellapenna. 1994. Reduction of tomato polygalacturonase $\beta$ subunit expression affects pectin solubilization and degradation during fruit ripening. Plant Cell 6:1623-1634.

Weigel, D. and E.M. Meyerowitz. 1994. The ABCs of floral homeotic genes. Cell 78:203-209.

Williams, R.R. 1965. The effect of summer nitrogen application on the quality of apple blossom. J. Hort. Sci. 40:31-41.

Yanofsky, M.F, H. Ma, J.L. Bowman, G.N. Drews, K.A. Feldmann, and E.M. Meyerowitz. 1990. The protein encoded by the Arabidopsis homeotic gene agamous resembles transcription factors. Nature 346:3539. 